\title{
The Internal Passive and the Periphrastic Passive in Journalistic Modern Standard Arabic
}

\begin{abstract}
By Yehudit Dror ${ }^{*}$
This paper aims to examine whether it might be argued that different passive structures in journalistic Arabic do not necessarily convey different semantic content, as reflected in recent research. It will be shown that it is not always possible to determine the precise intention of the author based on the passive structure, i.e. which aspect of the event he emphasizes - the process or the finished result.
\end{abstract}

Keywords: Internal Passive, Periphrastic Passive, Defocusing, Ambiguity, Process, Finished Result

\section{Introduction}

Arabic developed passive structures that are reflective of universal passive constructions, such as the internal passive, the periphrastic passive and the reflexive passive. The primary interest in this paper is the use of both internal passive and the periphrastic passive ${ }^{1}$, while the latter is one of the most prominent stylistic features of journalistic Arabic. The literature on the passive in modern standard Arabic discusses the two types of structures while trying to show the aspectual differences between them. However, the fact that the aspect of a verb is not reinforced by other indications in the text, raises the following issues that this article examines:

a. Can the internal passive be replaced by the periphrastic passive without changing the meaning of the utterance? Can these two structures simply be considered as stylistic variation with the same aspectual content?

b. If there is no proof which can reinforce the intention of the author, can the reader understand the described action in both ways, i.e. either as a completed action or as emphasizing the process?

c. Researchers such as Holes (1995), Murgida (1993) and Fisher et al. (2010) present additional differences between the internal and the periphrastic passive. The validity of these distinctions is also examined.

\footnotetext{
*Lecturer, Department of Arabic Language and Literature, University of Haifa, Israel.

${ }^{1}$ It is beyond the scope of this article to present an in-depth account of the term passive in Arabic. It will be only mentioned that the periphrastic passive in Arabic is formed by the verb tamma "completed, finish", which is usually referred to as dummy verb (Rosenhouse, 1985, p.94) or light verbs followed by a nominal verb.
} 
The discussion on the passive usages in journalistic Modern Standard Arabic is divided into two parts. In the second section (The Differences between the Internal Passive and the Periphrastic Passive) we present the aspectual and structural differences between the two types of passive presented by the scholars, while the third section (Analysis of Sentences Containing Internal Passive and Periphrastic Passive) attempts to prove by analyzing examples taken from the journals that such differences are not always valid.

\section{The Differences between the Internal Passive and the Periphrastic Passive}

This section presents the existing differences between the passive structures in written Arabic that are presented in the works of Murgida (1993), Holes (1995), and Fischer et al. (2010) ${ }^{1}$.

Aspectual Differences

Holes (1995) states that the widespread use of the periphrastic passive that is structured by tamma + verbal noun is to report the completion of a durative or iterative process. Thus, this structure rarely describes punctual events, cognitive activities or emotional states, where the focus is on the result of the process rather than on the process itself, e.g.:

(1) tamma ktišāfu 'ilāğin ğadīdin li-maraḍi s-sarațāni

"A new treatment for cancer has been discovered."

On the other hand, punctual actions are reported in journalistic Arabic by the use of the internal passive, e.g.:

(2) qutila țalātatu 'ašḩāṣin 'amsi 'atnāa'a ma 'rakatin

"Three people were killed yesterday during battle."

(3) wa qadi ktušifa l-harīru fì ș-ṣini fì 'àm 2640

"Silk was discovered in China in 2640 B.C."

(Holes, 1995, pp.258-259; Fischer et al., 2010, p. 33)

Example 1 exhibits durativity, i.e. it simply refers to the fact that the given situation, namely the discovery of the new treatment, lasted for a certain period of time (Comrie, 1976, p. 42). There is no doubt that the use of the auxiliary tamma, which is translated as "to be completed" (the discovery process was completed), indicates that the durative action came to its end, i.e. it is completed.

\footnotetext{
${ }^{1}$ Badawi (2002, pp.31-32), explains that the well-known auxiliary, as, for example, the French être or avoir, does not have the same grammatical value as a regular verbal predicate. He argues that the verb tamma in Arabic is not neutral like the auxiliary in French because it is considered a part of a complex predicate and thus can be labeled as VP (verbal phrase). Additionally, light verbs like tamma or ğarā tend to lose their original semantic meaning when they are introduced in the periphrastic passive.
} 
As for punctuality, this signifies that the situation does not last over time and takes place momentarily (Comrie, 1976, p.42). Therefore, according to Holes, example 2 could not be formed by the periphrastic passive *tamma qatlu talätati 'ašhāșin "the killing of three people was completed", because death in a battle is accidental, unpredictable and sudden - features that characterize a punctual action rather than a durative action. ${ }^{1}$ However, in examining example 3 - which is the opposite of example 1 - the internal passive might be explained by saying that the discovery of the silk was sudden, and thus can be considered as a punctual activity (Holes, 1995, p. 258). In other words, the difference between the sentences might be explained by the intention of the author which dictates the passive structure. If the intention of the author is to emphasize the process, he would chose the periphrastic passive (example 1), while by using the internal passive he would indicate the finished result (example 3 ).

The following difference belongs, according to the researchers, to the semantic domain; both Murgida (1993) and Holes (1995) mention that experiential verbs, i.e. verbs expressing cognitive activities, speech and emotional states, are typically passivized using the internal passive rather than the periphrastic passive, e.g.:

(4) tu 'tabaru hādihi l-muškilatu min 'ahammi l-mašākili

"This is considered to be one of the most important problems."

(Murgida, 1993, p.94; Holes, 1995, p. 259)

Additional specific expressions are mentioned by Fischer et al. (2010):

(5) hunā lā yul'abu wa-lā yusbahu

"Here, playing and swimming are prohibited." (*here will not be played and be swum)

(6) mād̄ā tabaqqā laka minhu? šay’un lā yuḍkaru

"What is left for you from him? Something that is not remembered (could be remembered)."

\section{Ambiguity caused by Orthography}

In addition to the semantic-aspectual differences noted in the previous examples, Murgida connects orthography and ambiguity, i.e. due to the lack of vowelization in journalistic Arabic, some verbs can be read as passive or active verbs. However, there are verbs whose orthography changes in passive verbs, which cause them to be unambiguous, as, for example, the verb 'ușība "was injured", which in active is formed as 'așāba (Murgida, 1993, p. 88).

In the following example the periphrastic passive is used:

(7) wa-'aḍâfat: tamma tašhīṣu maraḍ̄ bi-šaklin ḩāti'in 'indamā kuntu șagìiratan

\footnotetext{
${ }^{1}$ This argument of Holes can be refuted because intentional killing can happen during a war, therefore using in this case the periphrastic phrase is also possible.
} 
"She added: my sickness was falsely identified when I was little."

However, if the reader would have read the same sentence but with an internal passive (which is not vowelized in the original text), the reader could interpret it as an active verb "she adds: he incorrectly identified my sickness when I was little" (wa-'aḍa fat: šahașa maraḍi bi-šaklin hāṭi'in 'indamā kuntu sagìiratan). Accoding to Murgida (1993, p. 89), over sixty present of the examined expressions in her study are unambiguous.

\section{Syntactic Differences}

Murgida (1993) is the only researcher who referred to the clause type in which the passive structures occurs. According to the statistical data presented by Murgida, most of the passive structures (67\% of the total 51,600 tokens) occur in a subordinate clause, while only $32.9 \%$ of the tokens were in the main clauses. Both periphrastic and internal passives occur in a subordinate clause (Murgida, 1993, p. 86). This statistic does not indicate a significant difference between the passive structures. However, the examined corpus in this work shows one prominent syntactic difference, namely a pronoun suffixed to the verbal noun in the periphrastic structure, e.g.:

(8) wa-fí bayānin 'āhara dukira 'anna ră̆ulan yablugiu mina l-'umri 32 'àman min madīnati 'akkā tamma i 'tiqāluhu ba'da 'an ḍbițat bihawzatihi kammiyyatun kabìratun mina l-muhaddirāti

"In the last statement it was mentioned that a 32-year-old man from the city of Acre was arrested after a large amount of drugs was found in his possession."

The periphrastic passive occurs in a subordinate clause that is preceded by the particle 'anna. This particle attracts the word order SV, where the periphrastic passive actually functions as the predicate. Omitting the anaphoric suffixed pronoun from the verbal noun * dukira 'anna rağulan yablugi mina l'umri 32 'àman min madīnati 'akkā tamma i'tiqāl is grammatically incorrect. It should be clarified that the appearance of such suffixed pronouns is required when the word order is SV, where the anaphoric pronoun refers to the previously-mentioned subject. In clauses in which the internal passive is used, suffixation of an anaphoric pronoun to the verb would be incorrect grammatically, and thus such clauses are paraphrased as follows: dukira 'anna rağulan yablugiu mina l-'umri 32 'āman min madīnati 'akkā 'tuqila.

\section{Functional Differences}

Shibatani (1985) explains the function of the passive as follows:

"In other words, passives center around agents and their fundamental function has to do with the defocusing of agents. This is also observed from the fact that passivization does not generally apply to non-agentive intransitives, even in those languages where it applies to agentive intransitives." (Shibatani, 1985, p. 831) 
Murgida (1993) claims that the internal passive fits the passive prototype presented by Shibatani, i.e. there is focus on the object and defocusing of the agent. The periphrastic passive, however, does not fit the passive prototype framework of Shibatani because, according to Murgida, this passive structure shifts the focus away from both agent and object. The defocusing of the agent is caused by its deletion, while the object is defocused because it can sometimes appear in oblique case (Murgida, 1993, p. 119) as can be seen in example 7, where marad is in oblique case instead of nominative case. The oblique position has, according to Shibatani (1985), the lowest degree of focus among the syntactically-encoded elements (Shibatani, 1985, p. 833).

In conclusion, the researchers emphasize the differences between the passive structures in modern written Arabic. The following section tests the applicability of the arguments presented in this section.

\section{Analysis of Sentences Containing Internal Passive and Periphrastic Passive}

To prove the argument that both internal and periphrastic passives could have the same syntactic and aspectual indications, it is necessary to examine equivalent sentences, i.e. they must be in an identical context and written by the same author. Such equivalent sentences could not be found in the analyzed corpus, since the authors typically use the same passive structure in their articles. The lack of equivalent sentences may strengthen the argument that the different intentions of the authors and their writing habits are expressed by their choice of the passive structure. Yet, one cannot ignore the fact that there are many parallel sentences taken typically from the same source in which the indication of the passive structure is unequivocal and hence they can have another interpretation. The analyzed couplet sentences share the following features:

Syntactic properties:

- Both verbs have the same root and verb pattern in the same tense, number and person.

- Both clauses generally have the same clause type, i.e. main- or subordinate clause.

- In both clauses the agent is either mentioned or not. When it is not mentioned, it can be restored based on the context.

Semantic properties:

- Both verbs are either dynamic or static.

- The subject in both clauses is either human or non-human singular feminine, or masculine.

These clauses show that it is not always easy to determine what the author is trying to convey with his choice of the passive structure. 
It might be best to consider first the clauses in examples 9 to 15 , which share the same syntactic structure. The first example to be considered is example nine:

(9a) wa-qad tamma ḩtitāmu l-faqrati bi- 'arḍin '̄iqà 'iyyin (bānūrāmā 27.11.2013)

"The artistic piece was concluded by a musical piece." (9b) fì n-nihāyati htutima l-mu'tamaru bi-qat'i qālibi l-halwā (aššarq l-'awsaț 6.6.2012)

"At the end, the convention concluded with cutting a cake."

It seems that using the internal passive in 9a (htutimati l-faqratu) could be possible because the concluding part was not a process but rather a punctual event that lasted only a few minutes, so it may be well argued that in both sentences the action is punctual, and not durative. The ambiguity factor also should be considered when considering example 9a, because it would be grammatically and semantically correct to consider it active voice ${ }^{1}$ wa-qadi htatamati l-faqrata bi- 'ardin 'ìqa' 'iyyin "she finished the artistic show with a musical piece," although it is unclear from the context to whom the pronoun she refers. However, example $9 \mathrm{~b}$ cannot be ignored, where replacing the internal passive with an active verb is grammatically and semantically possible, yet no periphrastic passive that can prevent this ambiguity was used.

Similar to example 9, the action of announcement in both $10 \mathrm{a}$ and $10 \mathrm{~b}$ is punctual and accomplished rather than durative. Additionally, in both sentences reading the passive verb in active voice is possible, however example $10 \mathrm{~b}$, in which both active and passive reading is plausible, demonstrates that preventing ambiguity is not always a significant factor affecting the choice between internal or periphrastic passive.

As for the pragmatics, Murgida explained that in the periphrastic passive both the agent and the object are defocused. According to Murgida, the object is in oblique case because it appears in the genitive construction. However, this explanation cannot be used for example 10, because the verb 'a lana in this example (10a and 10b) is intransitive and requires the preposition 'an, so it is impossible to indicate here the defocusing of the object in the periphrastic passive.

(10a) tamma masā'a l-yawmi l-’i 'lānu 'an waqfi l-'ị̣rābi fi rawḍāti t-țīrati (bānūramā 19.11.2013)

"Today at evening the stopping of the strike in the kindergartens in the city of Tîra was announced."

(10b) wa-fì malta 'u'lina 'an wuṣūli 110 barịtāniyyina ba'da 'iğlà'ihim min lìbiyā (aš-šarq l-'awsaț 4.8.2014)

"The arrival of 110 British after their evacuation from Libya was announced in Malta."

\footnotetext{
${ }^{1}$ The orthography in the journal will appear إختتر, thus without vowelization one can read it as an active verb.
} 
Example 11 also shows that there is no aspectual difference between the internal and the periphrastic passive, since both $11 \mathrm{a}$ and $11 \mathrm{~b}$ indicate punctual action. Furthermore, it might be argued that the action in example ten (the announcement) and the action in example eleven (the issuing), which are considered punctual, are the result of a process. Thus, announcing something in public or issuing any decision requires a process involving consultation between those that are responsible for the matter. This process, which normally takes time, is accomplished when the decision is taken and can be announced.

(11a) wa-binā'an 'alā dāalika fa-qad tamma 'iṣdāru qarārin wizāriyyin bi-'inhā'i 'iğrā'āti t-tahqūqi (aš-šarq l-'awsat 20.10.2013)

"Based on this a ministerial decision was issued regarding completing the investigations' procedure."

(11b) wa-fì s-sā'ati t-tāsi'ati masā'an 'ușdira l-'amru ma'a musā'dati ̌̌s-šurtati (aš-šarq l-'awsaț 16.7.2012)

"At 9 o'clock in the evening this ('amr refers to the capture of a gang) was issued with the help of the police."

The aspectual similarity between the internal and the periphrastic passive can also be seen in example 12. The appointment action is punctual, while the selection's process of the delegate can be extended. The selection process was concluded by the selection.

(12a) tamma ta 'yīnu l-fannānati șābrīn ka-safïratin li-mu'assasati l'iḡâtati l-'islāmiyyati (bānūramā 19.11.2007)

"Șābrīn the artist was appointed as an ambassador of the Muslim aid institute."

(12b) kāna l-bašìr qas 'uyyina fí šubātin 'îtra 'iqālati salīm 'idrīs (aš-šarq l-'awsaț 6.8.2014)

"Bašīr was appointed in February following the dismissal of Salīm 'Idrīs."

The punctuality of an action expressed by both internal and periphrastic passives is also exemplified in example 13. The broadcasting action in 13a and $13 \mathrm{~b}$ is not durative since it speaks of the broadcasting of a specific episode and not of the complete series or in $13 \mathrm{~b}$ of a specific interview. Therefore, it would be impossible to argue that in 13a the context is used in order to say that the broadcast is a process which still functions, while in $13 \mathrm{~b}$ the broadcasting is completed.

As for the ambiguity factor, it seems that in this case it affects the choice of the periphrastic passive in 13a because this sentence can be read with active verb as follows: wa-qāla l-'amīru wīlyam li-šabakati CNN fì muqābalatin battati l-itnayni "Prince William said to the CNN network in an interview which (CNN) broadcast on Monday." Such ambiguity was not registered in $13 \mathrm{~b}$, so the sentence is expressed by using the internal passive. 
(13a) wa-qāla l-'amīru wīlyam li-šabakati CNN fì muqābalatin tamma battuhā l-itnayni 'inna ğūrŏg wulida fì landan (aš-šarq l'awsaț 6.7.2014)

"Prince William said to $\mathrm{CNN}$ in an interview which was broadcasted on Monday, that George was born in London."

(13b) takarrara ̂alika 'ahīran ba 'da halqatin tilifizyūniyyatin buttat 'alā t-tilifizyūni l-mișrī (an-nahār 20.4.2008)

"(The protests) repeated themselves lately after a TV episode was broadcasted on Egyptian television."

Example 14, unlike the preceding examples, presents two sentences taken from the same journalistic source and shares similar lexical items. Thus, this example could support the argument that the choice between the internal and the periphrastic passive is normally made due to stylistic variation, while aspectual and syntactic factors are not considered by the journalists. In both $14 \mathrm{a}$ and $14 \mathrm{~b}$ the action of saying welcoming words takes only a few minutes.

(14a) wa-'uqìmat 'alā šarafi ra'̄̄si wa-'a'ḍà'i l-wafdi wağbatu 'ašà'in (...) wa-ba 'dahā tamma 'ilqā'u kalimāti t-tarḥ̄bi bi-l-wafdi min qibali hürst krībs ra'īsi baladiyyati nūrtūrf (bānūramā 14.7.2009)

"And a dinner was held in honor of the head of the delegation and its members (...) and after the dinner words of welcome were said on behalf of Horst Krebs, the mayor of Nortov."

(14b) wa-ba'da stiqbāli t-țullābi 'ulqiyat kalimātu t-tarḥ̄ibi min qibali mudīrayi l-madrasatayni (bānūramā 20.8.2010)

"And after welcoming the pupils, words of welcome were said on behalf of the two principals of the two schools."

The two sentences in example 15 have similar content because they are taken from reports on returning archaeological items that were stolen from the museum of Malawī during the events of the Arab Spring in Egypt. It might be well argued that in both cases, the theft of the archaeological items was planned, because the primary intention of the people who attacked the museum was to steal its items. Furthermore, based on the context, one can understand that the people attacked the museum once (e.g. the word huğum in $15 \mathrm{a}$ in singular form) and during the attack many archaeological items were stolen. Thus, it would be inaccurate to say that 15 a indicates a durative action, while $15 \mathrm{~b}$ indicates a one-time and punctual action. Additionally, no case of ambiguity was registered in $15 \mathrm{a}$, i.e. grammatically and semantically considering the verb in the active voice would be incorrect. Also the argument of defocusing the agent and the object presented by Murgida cannot be implemented. According to her, the object is in the oblique case because it appears in the genitive construction. However, example 15a 84 qit' 'atan 'atariyyatan tamma sirqatuha exhibits the normal structure of a relative clause in which the relative clause modifies the direct object 84 qit'atan. The 
anaphoric pronoun suffixed to the verbal noun sirqa is grammatically obligatory. Thus, if the periphrastic passive occurs in a relative clause modifying the object (84 qit'atan) that does not function as nomen regens, how can it be argued that the object is defocused?

(15a) 'ista'āda mathafu malawī 84 qiț'atan 'atariyyatan tamma sirqatuhā 'ibbāna l-huğūmi 'alayhi min qibali ba'ḍi l-ğamā'āti lmutatarrifati (al-'ahrām 20.9.2013)

"The museum of Malawī has returned the archaeological items that were stolen during the attacks of extremist groups on it."

(15b) wa-bi- 'awdati t-timtāli yașilu 'adadu l-qița 'i l-'ațariyyati llatī tamma stirğ $\bar{a}$ 'uhā 'ilā naḥwi 800 min 'aṣli 1050 qiț'atan suriqat min mathafi malawī (an-nahār 19.1.2014)

"And by returning the statue, the number of the archaeological items that were returned has reached 800 of the original 1050 items that were stolen from the museum of Malawī (a city in Egypt)."

The next group to be analyzed includes examples 16 to 19 . This group is characterized by the different syntactic structure of each pair and they were chosen to demonstrate that such a difference has no influence on the aspect of the passive structure.

In example 16a, the periphrastic passive appears in a subordinate clause, while in $16 \mathrm{~b}$ the internal passive belongs to the main clause:

(16a) wa-'ašāra l-bāhị̂ūna 'ilā 'annahu tamma l- 'uțūru 'alā 'aktara min 'alfi qiț'atin min baqāyā 'aż̄matin (aš-šarq l-'awsat 21.11.2013)

"The researchers imply that more than 1000 pieces of huge human remains were found."

(16b) wa-qad 'uțira 'alā hādihi l-baqāyā fi mawqi'i šimāw l'atariyyi (an-nahār 4.12.2013)

"These (human) remains were found in the archaeological site of Shimaw."

It is possible to say that the periphrastic passive in 16a indicates the process of disclosing the remains, while $16 \mathrm{~b}$ indicates the result and not the process. It also might be argued that in 16a, the action of disclosure was planned, while in $16 \mathrm{~b}$ the disclosure happened accidentally. The problem with such claims stems from the lack of temporal indication in the text that might strengthen them, so there must be hesitation regarding these arguments, because both passive structures may express to the same degree, the process (durativity), punctuality, something planned or accidental. Example 16 can be used as evidence that defocusing of the object does not always characterize the periphrastic passive. In both clauses $16 \mathrm{a}$ and $16 \mathrm{~b}$, the object is actually a quasi- 
subject ${ }^{1}$ preceded by the preposition 'alā, i.e. in both cases the subject is in the genitive case rather than the nominative case, and thus it has the same degree of focus in the sentence. Finally, it should be mentioned that hypothetically $16 \mathrm{a}$ could be read as being in the active voice *wa-'ašăra l-bāhițūna 'ilā 'annahu 'atara 'alā 'aktara min 'alfi qiț'atin min baqāyā 'aẓimatin "the researchers imply that he found more than 1000 pieces of huge remains". Using the periphrastic passive in this case eliminates the ambiguity.

Same explanations presented in the previous example are applicable in example 17:

(17a) l-fuhūṣātu 'atbatat 'annahu lam yatimma l-kašfu 'an tağāâwuzāti 'aši 'atin (bānūramā 14.7.2009)

"The probes proved that excessive radiation was not found."

(17b) wa-mițla kulli 'amaliyyati t-tağassusi llatī kušifat (...) (ǎ́šsarq

l-'awsat 29.11.2013)

"And as every other spy operation that was revealed (...)"

In the section entitled Aspectual Differences, two clauses containing the passive structures ktušifa and tamma ktišăfu were mentioned. According to Holes (1995), the periphrastic passive indicates that the action of discovery is a process that lasts a certain period of time. The internal passive, however, indicates that the action happened suddenly without any planning and thus is considered a punctual action. Clearly, this distinction is appropriate for examples $17 \mathrm{a}$ and $17 \mathrm{~b}$; yet the question remains - how can one prove the certainty of such a claim? Examination of the context shows no specific indication that can prove that the discovery of spies is sudden and thus punctual. It seems that the punctuality is expressed rather in example 17a, because it might be that the probes were conducted over a short period, therefore finding the radiation is not durative but punctual. This argument can be well-accepted because no temporal indications appear in the context.

In example 18 the periphrastic passive appears in a subordinate clause (relative clause), while the internal passive starts a main clause. Despite this syntactic difference, it seems that the aspect of both passive forms is identical. Agreement on something is not an action taken randomly. It requires thought and consent of all the parties involved, and both passive forms indicate a process which ends by an agreement.

(18a) hadafu l-iğtimā'i llaḍ̂̄ tamma l-ittifāqu 'alā n'iqādihi huwa farḍu ttifāqin min 'ă̆li qiyāmi ḥukūmatin ntiqāliyyatin (al-'ahrām 1.12.2013)

\footnotetext{
${ }^{1}$ Fischer et al. (p. 29-31) calls the prepositional object a semi-subject. The object should be in the nominative case in the passive structure, but the preceding preposition causes the object to be in the genitive case.

${ }^{2}$ Reading the verb as active is acceptable only if the suffixed pronoun $h u$ in 'annahu functions as the subject and not as a dummy pronoun (damīr $\check{s}-\check{s} a$ 'n $n$ ).

${ }^{3}$ The orthography in the journal will appear as عל ع active or internal passive.
} 
"The purpose of the meeting which was agreed on is to impose an agreement for the establishment of a provisional government."

(18b) 'uttufiqa 'alā fathi l-ma'ābiri wa-'idhāli l-mawāddi l'asāsiyyati (aš-šarq l-'awsaṭ 29.11.2013)

"It was agreed to open the passageways and bring in basic material."

In example 19 the only difference between the two sentences is a syntactic one, i.e. relative sentence vs. main sentence. Both 19a and 19b, which are taken from the same journalistic source, refer to the publication of a specific study. The action of publication is considered punctual, while it is also the final stage of conducting a study, i.e. the publication of its result. Additionally, 19a shows that ambiguity or defocusing of the object does not much affect the choice of periphrastic passive. Semantically it is impossible to replace the passive form with the active form so the meaning would be that the study has published itself. As for the defocusing of the object, no object in genitive structure is exhibited here. The anaphoric pronoun suffixed to the verbal noun refers to the subject dirāsa.

(19a) 'akkadati d-dirāsatu llatī tamma našruhā fì l-mağallati l'amrikiyyati li-t-tag̣diyati t-țibbiyyati ș-șilata bayna tanāwuli lmašrūbāti s-sukkariyyati wa-s-sukkariyyi (aš-šarq l-'awsat 13.7.2011)

"The study that was published in the American journal of medical nutrition asserts the connection between drinking sweet soft drinks and diabetes."

(19b) hādihi d-dirāsatu nuširat fì n-nushati l-'iliktrūniyyati mina lmağallati t-țibbiyyati l-barîtāniyyati (aš-šarq l-'awsaț 29.8.2013)

"This study was published in the electronic version of the British medical journal."

The last two examples are classified in a third group, in which both the internal and the periphrastic passives indicate habituality or durativity.

(20a) (...) qtanati l-yūn̄̄sif 300 haymaitin muğahhazatin li-faṣli ššitā'i sa-yatimmu stih̆dāmuhā ka-fușūlin dirāsiyyatin (al-'ahrām 3.12.2003)

"UNICEF acquired 300 prepared tents for the winter, and they will be used as classrooms."

(20b) wa-tustahdamu ba 'ḍu l-wasā'ili t-taqlìdiyyati li-mukāfahati lğarìmati (aš-šarq l-'awsaț 29.6.2008)

"Some of the traditional means will be used for fighting the crime."

The prominent difference between examples $20 \mathrm{a}$ and $20 \mathrm{~b}$ is the tense, future vs. present. Thus, the periphrastic passive indicates a future action. However, one cannot avoid the question why the internal passive $s a$ tustahdamu in 20a is not used. This structure would also indicate that UNICEF has already acquired the tents and they will be used as soon as they are ready. 
Furthermore, in both structures habituality is also involved. Both sentences express that the use of the tents by UNICEF or the use of the traditional means is not a one-time action, but durative and habitual.

As in example 21, the action of broadcasting in both $21 \mathrm{a}$ and $21 \mathrm{~b}$ repeats itself at a specific time (i.e. same day and time). The broadcasting in both sentences happens in the present time. In addition the broadcast of one episode's last few minutes and that of the complete series is indeed durative, yet the broadcast period is limited in time. Finally, the orthography of the verb $y u d \bar{l}^{\prime}$ ' $u$ "broadcast" changes in passive, therefore the verb is unambiguous and there is no need to use the periphrastic passive in this case.

\section{(21a) bada'a li-'awwali marratin battu l-barāmiği t-ta 'limiyyati 'alā qanāti ș-șawți ššsa'bi haytu yatimmu 'id̄ā'atu l-murāğa'āti n- nihā'iyyati li-l-marāhili l-'i'dādiyyati wa-t-tânawiyyati l-'āmmati (al-'ahrām 17.5.2014) \\ "Today for the first time began the broadcasting of educational programs on the "peoples' voice" channel where the final reviews for the elementary stages (i.e. elementary schools) and high schools are broadcast." \\ (21b) barnāmiğu 'iskāl yud̄ā'u kulla hamīsin s-sā'ata r-rābi 'ata ba'da z-zuhri (an-nahār 6.7.2014) \\ "The program 'iskāl is broadcast every Thursday afternoon at four."}

\section{Conclusions}

Four main differences between the periphrastic passive and the internal passive were presented and examined in this paper. As for the aspect, it was shown that both structures can indicate durativity, habituality and punctuality. The argument of the researchers that the periphrastic passive can express the process, while the internal passive expresses the result could be true only if there were temporal indications proving this argument. It was shown, however, that such indications are usually missing from the text, and thus a periphrastic passive can indicate the finished result just as the internal verb can indicate the process.

The clause type was also mentioned as an optional difference. Here again it was proved that both structures can appear in subordinate or in main clauses.

As for the claim that the periphrastic passive is used when ambiguity might be involved due to orthography, it could be true if this structure was used only in cases where the internal passive could have been read as an active verb. The corpus indicates that the periphrastic passive is used in cases in which ambiguity cannot be considered for grammatical reasons.

As a final difference, the pragmatic issue was also raised by the researchers. It is agreed that the main function of the passive is defocusing the agent. Murgida added that in the case of the periphrastic passive, the object is also defocused because it is not in the nominative case but in the genitive, 
because it appears in the genitive construction. During the analysis of the examples, a reservation about this argument was expressed, because in some cases the pronoun which is suffixed to the verbal noun refers to the direct object or to the subject, as in example $8 \mathrm{a}$, where the pronoun refers to the subject rağul (or as it is called 'ism 'inna).

\section{References}

Badawi, M., 2002. A Propos des Aspects Lexicaux du Mağhūl Analytique en Arabe Moderne. Zeitschrift für Arabische Linguistik, 41, pp. 27-45.

Comrie, B., 1976. Aspect. London, New York and Melbourne: Oxford University Press.

Fischer, W., El-Ayoubi, H. \& Langer, M., 2010. Syntax der arabischen Schriftsprache der Gegenwart. Wiesbaden: Reichert.

Holes, C., 1995. Modern Arabic: Structures, Functions and Varieties. London: Longman.

Murgida, J., 1993. Passive and Passive-like Expressions in Journalistic Modern Standard Arabic. A Thesis Submitted in partial fulfillment of the Requirements of Georgetown University for the Degree of Doctor of Philosophy. Georgetown University.

Rosenhouse, J., 1985. Occurrence of the Passive and Pseudo-Intransitive Constructions in English and Arabic. Babel: International Journal of Translation, 34(2), pp. 90-103.

Shibatani, M., 1985. Passive and Related Constructions: A Prototype Analysis. Language, 61(4), pp. 821-848. 
